\title{
Reflective Field Experiences For Success In Teaching Elementary Mathematics
}

\author{
Shirley N. Robards, Ed.D, University of Tulsa, USA
}

\begin{abstract}
In this paper the author will discuss the major components of a junior level pedagogy course for elementary education majors learning to teach mathematics. The course reviews content and knowledge of the teacher candidates and introduces methods and materials for teaching elementary mathematics.
\end{abstract}

Keyword: teaching elementary mathematics, teacher education, field experiences

\section{INTRODUCTION}

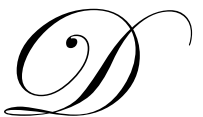

uring the past 20 years, research to support anchoring the teacher education program in laboratory preparation was recommended by professional educators. These carefully sequenced field experiences that are development and well organized with instructor feedback help to promote critical analysis and reflection for future teachers (Berliner, ${ }^{\mathrm{i}}$ Howey ${ }^{\mathrm{ii}}$ Robards, ${ }^{\mathrm{iii}}$ ). Based on these data from a statewide survey of teacher education programs, most of the programs had similar objectives, related courses, and hours required. The research took place in the context of planning and piloting activities with responses from the directors of field experiences in approved programs for preparing teachers in Oklahoma. The nature of the fieldbased activities and supervision practices were identified for the following levels of field experiences:

1. Level $1 \quad$ Introductory Field Experiences

2. Level II Field Experience to Understand Characteristics of Learners

3. Level III Field Experiences to Integrate and Apply Pedagogy

4. Level IV Student Teaching/Internships Teaching

5. Level V Residency Year Program

These data suggested several common threads in sequencing field experiences. Some Oklahoma institutions were requiring freshmen and/or sophomores to complete introductory field experiences. The time required for field experiences prior to student teaching increased, especially in secondary education. More of the field experiences were integrated with methods courses for elementary, early childhood, and secondary education. Although the student teaching experiences were, for the most part, traditional, several institutions were planning different approaches, such as the year-long internship or two semesters of student teaching combined with other education courses. Some interns spent 8 weeks at two different grade levels.

The course reviews content and knowledge of the teacher candidates and introduces methods and materials for teaching elementary mathematics using the Standards or benchmarks from the National Council of Teachers of Mathematics (NCTM). These NCTM Standards are current benchmarks from 1989, 1991, and 1995 and are built on the premise that all students can learn mathematics and that teachers play an important role of helping children and youth understand.

The basis for the research was done within the framework of the "scholarship of teaching and learning" (Shulman, 1999 $9^{\text {iv }}$ B Boyer, 1990v). According to Shulman, "teaching and learning in one's own discipline or profession are similar to a laboratory where all sorts of questions may occur." Instructors in academia are engaged in teaching, evaluating, and course design as we strive to revise and improve the instruction of teacher candidates. 
Thus, the college classroom becomes a natural place to conduct research in order to improve the quality of teaching and learning and to critically examine the teaching process and its affects on student learning (DeAngelis, 2003 ${ }^{\mathrm{vi}}$ )

\section{METHODS}

In the past, arithmetic was considered a synonym for mathematics. Some educators and parents viewed mathematics as limited to solving problems and computations or operations on numbers. This narrow view of mathematics as rote memorization of number facts and procedures did not promote understanding of number concepts. In a contemporary mathematics program a broader view of mathematics is the mission with the emphasis on understanding the basis mathematics concepts and processes as presented in the NCTM standards, including Problem Solving, Reasoning and Proof, Communication, Connections, Mathematical Representation, Number and Operations, Algebra, Geometry, Measurement and Data Analysis and probability (Heddens \& Speer, $2006^{\text {vii }}$ ). During the spring semester of 2008 , the ten elementary teacher candidates engaged in peer teaching and used selfanalysis or reflections, as well as feedback from peers, course instructor and practicing teachers. Reflective teaching, wrote Zeichner (p.1) in 1996, is learning to question yourself about thinking and analyzing the lesson elements and the context of the lesson. ${ }^{\text {viii }}$ University students were enrolled for the spring semester of 2008 in mathematics and science methods concurrently and spent 3 hours per week observing, teaching, and reflecting in the elementary mathematics and science classrooms of master teachers. Each teacher candidates at the end of the semester received 6 hours of credit upon completion of the coursework ( 3 hours for mathematics methods and 3 hours for science methods).

The courses were not lecture based. Teacher candidates were expected to engage in constructing meaning from the class activities, projects, class discussions on readings, methods, materials and field experiences. Satisfactory performance in the field experiences on Thursdays mornings with observations, teaching and reflections was required. A Collection of 6 lessons plans were developed to fit the scope and sequence for students in the assigned classrooms as a teaching requirement. Each lesson was written using a structured model that included student objectives, NCTM standards and at least 3 class activities at the concrete, pictorial and abstract levels. Other materials used in teaching included calculators, computers, internet, Smart Board and other manipulatives. After teaching each lesson, the teacher candidate wrote a 2-page reflection using the feedback sheets from the University representative, the master teacher and in some cases the peer observer. Reflections provided time to do the introspections and analyze the strengths of the lesson and areas that need to be improved. Basic expectations for each lesson included planning and teaching a standard-based lesson with an age-appropriate class.

\section{RESULTS}

Analysis of the responses to what he/she learned in the field experiences where lessons were planned and taught to students in the classroom are shown below:

Response 1: "I thought that $6^{\text {th }}$ graders would really intimidate the teacher, but just learned they're still students that need the information. The Block Schedule scared me at the middle level but I actually liked the schedule. This schedule enabled me to cover more concepts, review the information and complete several tasks all in one class period. Games were helpful and provided manipulatives for understanding. Sixth graders loved to use M \& M candies to understand decimals and percentages. Of course, we ate some!"

Response 2: "This semester I learned that teaching math is something that you can't be afraid. Really there was no reason to fear teaching math. I hate math; I'm gad at math; Thus, I thought I would hate teaching math and making the math lessons plans, but it turned out to be very creative. The methods' text book had very useful ideas for us to use and I will keep the textbook. In addition, I liked searching lesson plans on the computer and writing analysis of the lessons to share with peers in the class. I like the elementary school that I was assigned; it reminded me of a private school. The students in the public school were very nice and I learned a lot about adapting the lessons to the needs of the class. Going to the elementary school every Thursday was delightful and beneficial for my teaching skills." 
Response 3: "One of the most important things that I learned from the math methods class was the importance of using manipulatives in the classroom when presenting concepts. All of my personal experiences with math in elementary school were not very positive. I always remember just doing worksheets and not every really being able to use hands-on materials. My peer partner made sure to let the students be very kinesthetic and explore the concrete, pictorial and abstract levels of the concept (s) we were teaching. Then we let the children discover the world of mathematics using reasoning, communication, past knowledge and examples. Teaching mathematics successfully requires a hands-on, guided discovery for students to stay involved, interested and motivated. The children at the University School really challenged us! These gifted students were always wanting to learn more so my partner and I had to prepare extra activities to keep the pace of the class moving forward. This semester has been one of the most rewarding field experiences thus far. I have really gained a feel for how to teach mathematics to elementary children."

Response 4: "I have learned that when you teach math there will be times when you have to slow down and break down the harder concepts being taught. There are times when the concept seems easy in the teacher's mind, but he/she has to remember that the concepts may be new for students. I have also learned that then one way of teaching a concept is not working you have to be creative and flexible to think of an alternative way of getting students to learn. The field experience is a great opportunity for future teachers. It provided you an opportunity to teach before you have the total responsibility of students in the classroom. In addition, I learned what the expectations are for students in certain grades that helped me decide what level that I want to teach. The mentor teachers were also very helpful and can be useful contacts for future networking. The field experiences provided me with additional experiences in all subject areas."

Response 5: "When I first started by field experiences in math, I was scared to teach. Math was my least favorite subject in school, but after teaching I've found it can be really enjoyed. My partner and I found some really fun lessons that the students loved and were able to align the concepts with the benchmarks. From the class, I learned that there are many different methods of teaching math and that it is very important to begin learning the new concept at the concrete level with manipulatives and then work upward through the pictorial level to the abstract level of the concept(s). From the field experiences I learned that it is really important to develop your "signal" to show the students various behavioral expectations. Flexibility is very important, because I had lessons that had to become shower or increase the pace. I got a lot out of the math methods class and am glad that we had the field experience."

Response 6: "I learned how to teach math in different ways according to different students' needs. I never thought about the fact that students have very different way of thinking than adults do. A teacher had to be prepared for everything and also have to plan just in case of an emergency. I enjoyed the field experiences very much. Before we started the class in January 2008, I was very nervous about teaching math and dreaded the time that I would have to teach math. This experience helped me to learn that I can teach math just as I can teacher other subjects. The field experience gives teacher candidates a change to get over the fears of teaching and intiminidations of studentsyes, I can! “

Response 7: "I think the biggest think that I have learned about teaching mathematics this semester is the importance of creativity when introducing concepts. Looking at all of the different manipulative available for teaching mathematics, I have gotten a lot of ideas for fun activities to align with the standards. As we've all shared different lessons for the benchmarks from the computer search, I realized how much I wish math had be presented to me in these interactive ways when I was in elementary school. The field experience was very valuable. Teaching the students with manipulatives and seeing how helpful it was to them really confirmed my desire to try and use as many concrete lessons as I can when teaching the standards. The experience was also very valuable in recognizing that students are on all different levels of mathematics and learning what to do to meet all of their needs is a big challenge."

Response 8: "I learned that anytime you are introducing any math concepts, use manipulatives to give the students a concrete understanding of the standard. Otherwise, the lesson might not be understood if the teacher has to explain the information. It is a good idea for the Teacher to have plan B. The plan will come in handy if your original lesson fails. You need to be able to 'think outside the box and be able to explain things in multiple ways since not 
everyone thinks the same way. The field experiences were very useful since they actually put you in the classroom. If I didn't get to teach in the methods classes, I would not be as well-prepared for student teaching. This class gave me a chance to teach all types of students, including those with learning disabilities. Now I've had some success with teaching and have more confidence. The experiences also gave me great opportunities to work on classroom management. At first, I did not know how to manage 30 students, but after 2-3 days, I quickly began to improve my techniques and model some of the techniques for positive classroom climate. I learned from teaching math that I actually like it. I thought that I would be intimidated by students. “

\section{CONCLUSIONS}

Based upon the instructor's analysis of the Collection of Lesson Plans, the teacher candidates learned to write detailed plans using the NCTM Benchmarks. After the first two lessons, the lessons plans in most cases meet the rubrics for the class lesson plan model of 80 percent or better. Due to the privacy regulations, student grades were not presented in the findings. Unsatisfactory lesson plans for the first and second lessons taught in the assigned school had to be re-written in order for the student's performance to be acceptable. The major weaknesses of the teacher candidates' lessons plans were the methods that were planned for the lesson were not congruent with the objectives or age appropriate and did not include the concrete, pictorial and abstract levels to develop the objectives. The NCTM standards were noted in the lesson plan, but in some cases these benchmarks were not matched with the objectives of the lesson.

In summarizing the responses of 8 students enrolled in the class who completed the field experiences, these data show that the reflective field experiences in mathematics using national standard do have a positive influence on the preparation of elementary teachers. The teacher candidates were more self-confident, had more student success and learning and were able to create teaching and learning situations for the needs of students. Teaching undergraduate teacher candidates to include reflection is very important as follow-up. This introspection and selfanalysis helps educators think about the strengths of the lesson and whether the objectives were achieved. The professional should think about the impact of the lessons on students. Did the students learn and what should I do next time to make the lesson better?

Weaknesses of the study include the small sample of elementary education majors participating in the study. The study with teacher candidates should be continued in order to see the trends of the data. Another component could be added to survey the attitudes of the teacher candidates before the course begins on knowledge of the methods of teaching mathematics and also at the end of the course.

\section{Endnotes}

${ }^{\mathrm{i}}$ Berliner, D. C. (1985). Laboratory settings and the study of teacher education, Journal of Teacher Education, 36(6),pp2-8.

${ }^{i i}$ Howey, Ken (1996). Designing coherent and effective teacher education programs, Handbook of Research on Teacher Education, Second Edition, John Sikula, Senior Editor p. 166.

${ }^{i i i}$ Robards, S. (1999). Sequencing Field Experiences in Oklahoma Teacher Education Programs, Paper presented to the Association of Teacher Educators, National Conference, Chicago, IL.

${ }^{\text {iv }}$ Shulman, Lee S. (1999). Taking learning seriously, Change Magazine, 10-17.

${ }^{v}$ Boyer, Ernest L. (1990). Scholarship Reconsidered: Priorities of the Professoriate. Princeton, NJ: The Carnegie Foundation for the Advancement of Teaching.

${ }^{\text {vi }}$ DeAngelis, Tori (2003). Higher-education movement aims to elevate teaching, Monitor on Psychology, Volume 34 , No. 8 September 2003, 5pp.

vii Heddens, J.W. \& W. R. Speer (2006). Today's Mathematics: Concepts, Classroom Methods, and Instructional Activities. NJ: John Wiley, Jossey-Bass Education, 421p.

viii Zeichner, K.M. and D.P. Liston (1996). Reflective Teaching, An Introduction. Lawrence Eribaum Associates. 92p. 